ZEIST, AR; RESENDE, JTV; FARIA, MV; GABRIEL, A; ADRIANO, E; LIMA FILHO, RB. 2018. Photosynthetic characteristics in species and interspecific hybrids of tomato. Horticultura Brasileira 36:362-370.DOI - http://dx.doi.org/10.1590/S0102-053620180313

\title{
Photosynthetic characteristics in species and interspecific hybrids of tomato
} André R Zeist; Juliano TV Resende; Marcos V Faria; André Gabriel; Elisa Adriano; Renato B Lima Filho ${ }^{1}$

1Universidade Estadual do Centro-Oeste(UNICENTRO), Guarapuava-PR, Brazil; andre.zeist@bol.com.br; jvresende@uol.com.br; mfaria@ unicentro.br; andre.gb85@hotmail.com; elisaadrianojd@gmail.com; delimafilho.renato@yahoo.com

\begin{abstract}
Gas exchanges in species and interspecific hybrids of tomato in different environments may contribute to the development and selection of genotypes with a higher tolerance to adverse cultivation conditions. This study aimed to assess the photosynthetic characteristics of wild tomato species and the cultivar Redenção, as well as the respective $F_{1}$ hybrids of interspecific crosses cultivated under two environments. The experimental design was a randomized block design with three replications and the assessment of six wild accessions, one cultivar, and the respective interspecific hybrids under two environments. At 14, 28, 42, 56, and 70 days after transplanting (DAT), gas exchange characteristics were assessed by means of a portable photosynthesis measurement system. The stomatal density of abaxial and adaxial surfaces of first-order leaflets was estimated under a protected cultivation at 56 DAT. We observed a higher influence of wild tomato species and interspecific hybrids on the assessed characteristics when compared to the cultivation environments. The accession 'LA-716' and the hybrid 'Redenção' $\times$ 'LA-716' presented the highest water use efficiency and the accessions 'PI-127826' and 'PI-134417' and the interspecific hybrids 'Redenção' × 'PI-127826' and 'Redenção' × 'PI-134417' presented the highest values of $\mathrm{CO}_{2}$ assimilation, transpiration, instantaneous in vivo carboxylation efficiency of Rubisco, and number of stomata on the abaxial leaflet surface. Thus, the descendants of Solanum habrochaites are an interesting alternative to breeding programs that aim to make advances in obtaining strains that exhibit improvement in their photosynthetic characteristics.
\end{abstract}

Keywords: Solanum lycopersicum, wild accessions, pre-breeding, gas exchange.

\begin{abstract}
RESUMO
Características fotossintéticas em espécies e híbridos interespecíficos de tomateiro
\end{abstract}

As trocas gasosas em espécies e híbridos interespecíficos de tomateiro em diferentes ambientes podem contribuir para o desenvolvimento e seleção de genótipos com maior tolerância às condições adversas de cultivo. O objetivo deste trabalho foi avaliar características fotossintéticas em espécies silvestres de tomateiro e na cultivar Redenção, bem como dos respectivos híbridos F1 de cruzamentos interespecíficos cultivados em dois ambientes. $\mathrm{Na}$ condução do experimento utilizou-se delineamento de blocos ao acaso, com três repetições, avaliando-se seis acessos silvestres, uma cultivar e os respectivos híbridos interespecíficos em dois ambientes. Aos 14, 28, 42, 56 e 70 dias após o transplantio (DAT), avaliaram-se características de trocas gasosas por meio do sistema portátil de medidas de fotossíntese. No cultivo protegido, aos 56 DAT, foi estimada a densidade de estômatos das faces abaxial e adaxial dos folíolos de primeira ordem. Foi observada maior influência das espécies silvestres de tomateiro e híbridos interespecíficos do que dos ambientes de cultivo nas características avaliadas. $\mathrm{O}$ acesso 'LA-716' e o híbrido 'Redenção' × 'LA-716' apresentaram a maior eficiência do uso da água e os acessos 'PI-127826' e 'PI-134417' e os híbridos interespecíficos 'Redenção' × 'PI-127826' e 'Redenção' × 'PI-134417', apresentaram os maiores resultados de assimilação de $\mathrm{CO} 2$, transpiração, eficiência instantânea de carboxilação in vivo da Rubisco e número de estômatos na superfície abaxial dos folíolos. Demonstrou-se assim, que os descendentes da espécie $S$. habrochaites são uma interessante alternativa para os programas de melhoramento genético, que desejarem realizar avanços na obtenção de linhagens e que apresentem melhoria nas características fotossintéticas.

Palavras-chave: Solanum lycopersicum, acessos silvestres, prémelhoramento genético, trocas gasosas.

Received on June 13, 2017; accepted on April 6, 2018

$\mathrm{R}$ esearch and teaching institutions have increasingly invested in characterizing plant genetic resources (Hilsdorf \& Hallerman, 2017). Activities related to plant pre-breeding are of paramount importance considering their proposal to solve problems arising from the narrowing of the genetic base of cultivated species and promote an increase in the efficiency of breeding programs.

In addition to the variety cerasiforme, tomato (Solanum lycopersicum) has several wild species that have higher or lower interspecific compatibility of crosses (Peralta et al., 2008). These wild species do not present commercial characteristics since they have small and usually pubescent fruits. However, these wild species are promising for use in breeding programs because they possess resistance genes, which, when properly studied and known, can be introduced into the cultivated tomato (Lucini et al., 2015).

Several tomato species have characteristics that enable the development and vegetative growth under diverse soil and climatic conditions because they are native to regions that comprise a wide range of habitats located along the west coast of South America, encompassing mainly the Andes of Ecuador, Peru, northern Chile, and the Galapagos Islands (Peralta et al., 2008; Bergougnoux, 2014). 
These characteristics are due to some biological functions present in wild species, which can be incorporated into the cultivated tomato. Among these functions, there are those that confer resistance to phytopathogens (Hurtado et al., 2012), arthropodpests (Lucini et al., 2015), abiotic stresses (Morales et al., 2015), and improvements in nutritional quality. However, studies are still needed to identify new characteristics that may be of interest to tomato breeding programs.

Several studies have reported the photosynthetic performance of tomato cultivated under the most diverse management conditions (Soares et al., 2012; Ramos et al., 2015, Zeist et al., 2017a). However, little is known about the photosynthetic characteristics of wild species and interspecific hybrids in comparison to the cultivated tomato. Even for plants of the same species, photosynthesis rate may vary between cultivars (Driever et al., 2014). Thus, gas exchange rates may have great variations among tomato species.

The qualitative and quantitative photosynthetic performance of plants is an important indicator of productivity (Zeist et al., 2017a,b) and mainly of tolerance to biotic (Bilgin et al., 2010) and abiotic stress (Saibo et al., 2009; Gururani et al., 2015; Morales et al., 2015). Thus, basic studies on the behavior of gas exchanges of species and interspecific hybrids of tomato plants under different environments can contribute to the understanding of genotype-environment interactions and, consequently, collaborate for the development and selection of cultivars with a higher tolerance to adverse conditions of cultivation.

Considering that, the aim of this study was to assess photosynthetic characteristics of wild tomato species and the cultivar Redenção, as well as the respective $F$ hybrids of interspecific crosses cultivated under two environments.

\section{MATERIAL AND METHODS}

The experiments were carried out in the agricultural season 2015/2016 at the Center for Research in Vegetables of the Department of Agronomy of the State University of Midwest (UNICENTRO), located in Guarapuava, PR, Brazil $\left(25^{\circ} 38^{\prime} \mathrm{S}, 51^{\circ} 48^{\prime} \mathrm{W}\right)$. The soil of Guarapuava is classified as a very clayey Oxisol (Latossolo Bruno, Brazilian System of Soil Classification).

Six wild accessions ( $S$. pimpinellifolium accession 'AF 26970', S. galapagense accession 'LA-1401', $S$. peruvianum accession 'AF 19684', $S$. habrochaites var. hirsutum accession 'PI-127826', S. habrochaites var. glabratum accession 'PI-134417', and S. pennellii accession 'LA-716') and the commercial cultivar Redenção (strain of $S$. lycopersicum with processing characteristics), together with the respective interspecific hybrids obtained from crosses between 'Redenção' (female parent) and wild accessions (male parents) ('Redenção' $\times$ 'AF 26970', 'Redenção' × 'LA-1401', 'Redenção' × 'PI-127826', 'Redenção' × 'PI-134417', and 'Redenção' × 'LA716') were assessed. The genotypes were assessed in a randomized block design with three replications and under protected (greenhouse) and external (field) environments. Each plot consisted of eight plants.

In order to obtain interspecific hybrid seeds, fruits developed from the crosses between 'Redenção' and wild accessions were collected and had their seeds taken. The sowing of these seeds and their parents was carried out in 200-cell expanded polystyrene trays containing bio-stabilized pine bark-based commercial substrates and maintained in a floating hydroponic system in a greenhouse.

Sowing of the accessions 'AF 26970' and 'AF 19684' and interspecific hybrids was carried out together with the 'Redenção' strain. In addition, sowing of the accessions 'LA-1401', 'PI-127826', 'PI-134417', and 'LA-716' was performed ten days earlier due to their difference regarding germination, emergence, and development. Seedlings were transplanted 27 days after emergence of the female parent when they presented 4 to 5 expanded leaves (December 22, 2015).

The experiment conducted in the protected environment used a compartment inside the greenhouse with evaporative air cooling by means of an exhaust fan and running water in expanded clay installed in opposite sides. In this environment, seedlings were transplanted into $8-\mathrm{dm}^{3}$ capacity pots containing sieved soil mixed with decomposed bovine manure in the proportion 3:2. For the experiment in the external environment, an area $110 \mathrm{~m}$ far from the greenhouse was used. This area was plowed and $1.0 \mathrm{~m}$ wide seedbeds were prepared with a rotary tiller.

In the experimental units of the protected environment, the pots containing the plants were placed in four rows spaced $0.40 \mathrm{~m}$ from each other and $0.40 \mathrm{~m}$ between plants. In the external environment, each experimental unit consisted of two continuous rows of transplanted plants spaced $0.90 \mathrm{~m}$ from each other and $0.40 \mathrm{~m}$ between plants.

In both environments, the soil was corrected according to soil chemical analysis by applying calcitic limestone to raise base saturation to $80 \%$ and maintain the $4: 1$ ratio between $\mathrm{Ca}$ and $\mathrm{Mg}$. Planting fertilization was carried out with 15 g NPK fertilizer (04-2020) and $7.0 \mathrm{~g}$ simple superphosphate per plant. Micro-drippers were used to irrigate plants, according to crop needs and based on the criteria established for tomato in each environment.

During experimental period, daily minimum and maximum air temperature data for the external environment were collected at an automatic meteorological station of the State University of Midwest, Campus Cedeteg, located 180 $\mathrm{m}$ from the experiment. In the protected environment, data were collected daily using thermometers of maximum and minimum temperatures. Minimum temperatures ranged from 13.7 (March 1,2016 ) to $21.8^{\circ} \mathrm{C}$ (December 31, 2015) and maximum temperatures from 26.3 (February 27,2016 ) to $33.9^{\circ} \mathrm{C}$ (January $9,2016)$. In the external environment, minimum temperatures ranged between 13.2 (March 1, 2016) and $21.0^{\circ} \mathrm{C}$ (December 22, 2015) and maximum temperatures between 22.6 (January 1, 2016) and $30.0^{\circ} \mathrm{C}$ (February 15, 2016).

Gas exchange was assessed by means of a portable photosynthesis 
measurement system (IRGA, Infrared Gas Analyzer, LI-COR, LI6400XT) with $1000 \mu \mathrm{mol}$ photons $\mathrm{m}^{-2} \mathrm{~s}^{-1}, 400$ $\mu \mathrm{mol} \mathrm{mol}{ }^{-1} \mathrm{CO}_{2}$, and $\Delta \mathrm{CO}_{2}+\Delta \mathrm{H}_{2} \mathrm{O}$ lower than $1 \%$, by determining net $\mathrm{CO}_{2}$ assimilation $\left(A, \mu \mathrm{mol} \mathrm{CO}_{2} \mathrm{~m}^{-2} \mathrm{~s}^{-1}\right)$, internal $\mathrm{CO}_{2}$ concentration $(\mathrm{Ci}, \mu \mathrm{mol}$ $\left.\mathrm{mol}^{-1}\right)$, and transpiration rate $(E, \mathrm{mmol}$ $\left.\mathrm{H}_{2} \mathrm{O} \mathrm{m}^{-2} \mathrm{~s}^{-1}\right)$. From these data, we quantified water use efficiency (WUE, mmol $\mathrm{H}_{2} \mathrm{O}^{-1}$ ) and the instantaneous in vivo carboxylation efficiency of Rubisco $(\mathrm{EiC})$, estimated by the relation between net $\mathrm{CO}_{2}$ assimilation and transpiration rate $(A / E)$ and the relation between net $\mathrm{CO}_{2}$ assimilation and internal $\mathrm{CO}_{2}$ concentration in the leaf $(\mathrm{A} / \mathrm{Ci})$, respectively.

In the protected environment, stomatal density (SD) was estimated at 56 days after transplanting in the two central plants of each plot by collecting leaf discs of $1 \mathrm{~cm}$ in diameter from the primary leaflets and fixed with carbon tape on a metal support, with subsequent analysis of $300 \mu^{2}$ of the abaxial and adaxial surfaces in a Tescan ${ }^{\circledR}$ Vega3 scanning electron microscope (SEM) with coupled camera. In order to facilitate stomata counting, leaflet surfaces were photographed.

Data of evaluated characteristics were tested for normality and homogeneity of residual variances by the Lilliefors and Bartlett tests, respectively, and later submitted to individual and joint analysis of variance. When F-test was significant, means were submitted to Scott-Knott cluster test at 5\% probability and analyzed by ASSISTAT statistical program version 7.7 (Silva \& Azevedo, 2016).

\section{RESULTS AND DISCUSSION}

In general, we observed a much higher influence of genotypes on gas exchange characteristics assessed at different days after transplanting when compared to cultivation environments, thus demonstrating the existence of a diversity of photosynthetic behaviors among the studied tomato species.

In the five assessment dates, the highest values of net $\mathrm{CO}_{2}$ assimilation $(A)$ and instantaneous in vivo carboxylation efficiency of Rubisco $(E i C)$ were observed for the wild species S. habrochaites var. hirsutum accession 'PI-127826' and S. habrochaites var. glabratum accession 'PI-134417' and the interspecific hybrids 'Redenção' × 'PI-127826' and 'Redenção' × 'PI-134417'. In general, the highest transpiration values $(E)$ and lowest internal $\mathrm{CO}_{2}$ concentrations $(\mathrm{Ci})$ were also observed for these wild species and respective interspecific hybrids (Tables 1 to 4 ). These results showed that the $\mathrm{F}_{1}$ hybrids 'Redenção' $\times$ 'PI127826' and 'Redenção' × 'PI-134417' inherited characteristics related to the photosynthetic behavior of the male parents 'PI-134417' and 'PI-127826'.

For the parents 'PI-127826' and 'PI-134417' and hybrids 'Redenção' × 'PI-127826' and 'Redenção' × 'PI134417 ', higher values of $A, E$, and $E i C$ were inversely related to $C i$ (Tables 1 to 4$)$. It is assumed that the lower $\mathrm{CO}_{2}$ concentration in the substomatal chamber of these plants is related to a higher use of $\mathrm{CO}_{2}$ by ribulose-1,5bisphosphate carboxylase oxygenase (Rubisco) in the Calvin cycle for the synthesis of P-trioses. The lower $C i$ in plants tends to stimulate stomatal opening and transpiration, thus allowing a higher $\mathrm{CO}_{2}$ entry into the substomatal spaces, which, consequently, promotes a higher net $\mathrm{CO}_{2}$ assimilation (Zeist et al., 2017b), as observed for 'PI-127826' and 'PI-134417' and hybrids 'Redenção' × 'PI-127826' and 'Redenção' × 'PI$134417^{\prime}$.

Gas exchange rates for the accessions 'PI-127826' and 'PI134417 ' of the species $S$. habrochaites and the respective hybrids with the cultivar Redenção stood out, which is in accordance with several studies in the literature (Liu et al., 2012; Ealson et al., 2014; Poudyala et al., 2015). These authors have observed that this species, because it is adapted to a wide range of latitudinal distribution, presents characteristics that allow better photosynthetic behavior even when conditions during the day or along the cycle are not favorable for the development of other tomato species.

Regarding the interaction genotype $\times$ environment, 14 days after transplanting (beginning of plant development), the cultivar 'Redenção' (female genitor), the wild accessions' LA-1401', 'AF 19684', 'PI-127826', and 'PI-134417' (male parents), and the respective hybrids presented a higher transpiration rate when cultivated under protected environment. This result is possibly due to a higher net $\mathrm{CO}_{2}$ assimilation observed in the protected environment when compared to the external environment (Table 1).

According to Ferraz et al. (2012), the increase or decrease of photosynthetic yield may be directly related to the transpiration rate. This occurs because the lower the gas diffusion of $\mathrm{H}_{2} \mathrm{O}$ is, the more limiting the net $\mathrm{CO}_{2}$ assimilation (Adams et al., 2016). In addition, the male parent 'LA-716' of the species $S$. pennellii and the hybrid 'Redenção' × 'LA-716' presented both lower transpiration rates and net $\mathrm{CO}_{2}$ assimilation at the same time in all assessment days.

In general, the wild accessions ' $\mathrm{AF}$ 26970', 'LA-1401', and 'AF 19684', as well as cultivar 'Redenção' and the respective interspecific hybrids 'Redenção' × ‘AF 26970', 'Redenção' × 'LA-1401', and 'Redenção' × 'AF 19684' presented a similar performance for gas exchange characteristics in all assessments (Tables 1 to 4). In addition, the values of net $\mathrm{CO}_{2}$ assimilation obtained for the strain "Redenção" are close to those reported for the species S. lycopersicum (Soares et al., 2012; Ramos et al., 2015; Zeist et al., 2017a).

At 14 days after transplanting, the genotypes cultivated in protected environment presented higher transpiration rate, which reflected in lower water use efficiency (Table 3). At 56 days after transplanting, the lowest internal $\mathrm{CO}_{2}$ concentration without increment of net $\mathrm{CO}_{2}$ assimilation in the protected environment in relation to the external environment (Table 4) for the wild accessions 'AF 19684', 'PI-134417', and 'LA-716', the cultivar Redenção, and the interspecific hybrids 'Redenção' × 'LA-1401', 'Redenção' × 'AF 19684', 'Redenção' × 'PI127826', and 'Redenção' × 'PI-134417' is possibly due to the lower carbon dioxide availability in the protected 
Table 1. Net $\mathrm{CO}_{2}$ assimilation $(A)$, internal $\mathrm{CO}_{2}$ concentration $(C i)$, and transpiration rate $(E)$ for species and interspecific hybrids of tomato cultivated under protected (P) and external (E) environments at 14, 28, and 42 days after transplanting. Guarapuava, UNICENTRO, $2015 / 2016$.

\begin{tabular}{|c|c|c|c|c|c|c|c|c|c|}
\hline \multirow{2}{*}{ Genotype } & \multicolumn{3}{|c|}{$A\left(\mu \mathrm{mol} \mathbf{C O}_{2} \mathbf{m}^{-2} \mathrm{~s}^{-1}\right)$} & \multicolumn{3}{|c|}{ Ci $\left(\mu \mathrm{mol} \mathrm{\textrm {mol } ^ { - 1 } )}\right.$} & \multicolumn{3}{|c|}{$E\left(\mu \mathrm{mol} \mathbf{H}_{2} \mathbf{O} \mathbf{~ m}^{-2} \mathbf{s}^{-1}\right)$} \\
\hline & $\mathbf{P}$ & $\mathbf{E}$ & $\overline{\text { Average }}$ & $\mathbf{P}$ & $\mathbf{E}$ & $\overline{\text { Average }}$ & $\mathbf{P}$ & $\mathbf{E}$ & Average \\
\hline & \multicolumn{9}{|c|}{14 days } \\
\hline Redenção & $17.6^{\mathrm{ns}}$ & 14.6 & $16.1 \mathrm{c}$ & $160.2^{\mathrm{ns}}$ & 159.6 & $159.9 \mathrm{a}$ & $2.3 \mathrm{Ac}$ & $1.7 \mathrm{Bc}$ & $2.0 \mathrm{~d}$ \\
\hline AF 26970 & 17.7 & 16.2 & $16.9 \mathrm{~b}$ & 152.4 & 153.7 & $152.1 \mathrm{a}$ & $1.3 \mathrm{Ad}$ & $1.2 \mathrm{Ad}$ & $1.3 \mathrm{e}$ \\
\hline LA-1401 & 15.4 & 15.8 & $15.6 \mathrm{c}$ & 156.6 & 166.1 & $161.4 \mathrm{a}$ & $2.3 \mathrm{Ac}$ & $1.6 \mathrm{Bc}$ & $2.0 \mathrm{~d}$ \\
\hline AF 19684 & 15.7 & 12.5 & $14.1 \mathrm{c}$ & 155.8 & 164.2 & $160.0 \mathrm{a}$ & $2.4 \mathrm{Ac}$ & $1.7 \mathrm{Bc}$ & $2.0 \mathrm{~d}$ \\
\hline PI-127826 & 20.1 & 19.4 & $19.7 \mathrm{a}$ & 106.3 & 113.3 & $109.8 b$ & $3.5 \mathrm{Ab}$ & $2.6 \mathrm{Bb}$ & $3.0 \mathrm{~b}$ \\
\hline PI-134417 & 20.2 & 20.9 & $20.6 \mathrm{a}$ & 107.0 & 107.6 & $107.3 \mathrm{~b}$ & $3.5 \mathrm{Ab}$ & $2.2 \mathrm{Bb}$ & $30 . \mathrm{b}$ \\
\hline LA-716 & 17.2 & 17.2 & $17.2 \mathrm{~b}$ & 156.5 & 165.4 & $160.9 \mathrm{a}$ & $1.0 \mathrm{Ad}$ & $0.9 \mathrm{Ad}$ & $0.9 \mathrm{e}$ \\
\hline Redenção x AF 26970 & 18.0 & 17.8 & $17.9 \mathrm{~b}$ & 163.5 & 163.6 & $163.5 \mathrm{a}$ & $2.5 \mathrm{Ac}$ & $2.4 \mathrm{Ab}$ & $2.5 \mathrm{c}$ \\
\hline Redenção x LA-1401 & 18.0 & 17.0 & $17.51 \mathrm{~b}$ & 162.5 & 162.6 & $162.5 \mathrm{a}$ & $2.8 \mathrm{Ac}$ & $1.9 \mathrm{Bc}$ & $2.3 \mathrm{c}$ \\
\hline Redenção x AF 19684 & 16.6 & 14.5 & $15.6 \mathrm{c}$ & 161.1 & 161.4 & $161.3 \mathrm{a}$ & $2.6 \mathrm{Ac}$ & $1.8 \mathrm{Bc}$ & $2.2 \mathrm{~d}$ \\
\hline Redenção x PI-127826 & 20.5 & 20.2 & $20.4 \mathrm{a}$ & 127.5 & 120.5 & $124.0 \mathrm{~b}$ & 4.2Aa & $3.5 \mathrm{Ba}$ & $3.8 \mathrm{a}$ \\
\hline Redenção x PI-134417 & 21.3 & 20.0 & $20.7 \mathrm{a}$ & 121.7 & 127.3 & $124.5 b$ & $3.3 \mathrm{Ab}$ & $3.3 \mathrm{Aa}$ & $3.3 b$ \\
\hline Redenção x LA-716 & 15.8 & 15.4 & $15.6 \mathrm{c}$ & 170.1 & 161.3 & $165.7 \mathrm{a}$ & $1.3 \mathrm{Ad}$ & $1.1 \mathrm{Ad}$ & $1.2 \mathrm{e}$ \\
\hline Average & $18.0 \mathrm{~A}$ & 17.0B & & $146.3 \mathrm{~A}$ & $148.2 \mathrm{~A}$ & & $2.5 \mathrm{~A}$ & $2.0 \mathrm{~B}$ & \\
\hline \multirow[t]{2}{*}{ CV $(\%)$} & & 8.4 & & & 13.7 & & & 13.4 & \\
\hline & \multicolumn{9}{|c|}{28 days } \\
\hline Redenção & $15.1^{\mathrm{ns}}$ & 17.2 & $16.1 \mathrm{c}$ & $176.1^{\mathrm{ns}}$ & 169.3 & $172.7 \mathrm{a}$ & $3.8^{\mathrm{ns}}$ & 3.7 & $3.8 \mathrm{~b}$ \\
\hline AF 26970 & 17.4 & 16.9 & $17.2 \mathrm{c}$ & 178.9 & 150.1 & $164.5 \mathrm{a}$ & 3.8 & 4.1 & $4.0 \mathrm{~b}$ \\
\hline LA-1401 & 19.5 & 20.4 & $20.0 \mathrm{~b}$ & 157.3 & 152.4 & $154.8 \mathrm{a}$ & 3.9 & 3.7 & $3.8 \mathrm{~b}$ \\
\hline AF 19684 & 17.5 & 17.6 & $17.5 \mathrm{c}$ & 174.5 & 155.1 & $164.8 \mathrm{a}$ & 3.7 & 4.1 & $3.9 b$ \\
\hline PI-127826 & 22.3 & 22.6 & $22.4 \mathrm{a}$ & 77.8 & 64.2 & $71.0 \mathrm{c}$ & 4.0 & 4.5 & $4.3 \mathrm{a}$ \\
\hline PI-134417 & 23.0 & 23.6 & $23.3 \mathrm{a}$ & 66.0 & 115.0 & $90.5 \mathrm{c}$ & 4.4 & 4.1 & $4.2 \mathrm{a}$ \\
\hline LA-716 & 19.2 & 18.9 & $19.0 \mathrm{c}$ & 167.2 & 159.9 & $163.1 \mathrm{a}$ & 3.2 & 3.1 & $3.1 \mathrm{c}$ \\
\hline Redenção x AF 26970 & 15.1 & 15.5 & $15.3 \mathrm{c}$ & 125.4 & 112.9 & $119.1 \mathrm{~b}$ & 3.3 & 4.2 & $3.8 \mathrm{~b}$ \\
\hline Redenção x LA-1401 & 17.1 & 17.6 & $17.4 \mathrm{c}$ & 168.5 & 153.6 & $161.0 \mathrm{a}$ & 4.0 & 4.0 & $4.0 \mathrm{~b}$ \\
\hline Redenção x AF 19684 & 15.7 & 18.2 & $16.9 \mathrm{c}$ & 143.4 & 154.4 & $148.9 \mathrm{a}$ & 3.9 & 3.9 & $3.9 b$ \\
\hline Redenção x PI-127826 & 22.1 & 21.8 & $21.9 \mathrm{a}$ & 97.7 & 113.5 & $105.6 \mathrm{~b}$ & 4.3 & 4.6 & $4.4 \mathrm{a}$ \\
\hline Redenção x PI-134417 & 23.0 & 22.6 & $22.7 \mathrm{a}$ & 82.3 & 74.3 & $78.3 \mathrm{c}$ & 4.6 & 4.3 & $4.4 \mathrm{a}$ \\
\hline Redenção x LA-716 & 17.6 & 18.9 & $18.2 \mathrm{c}$ & 130.0 & 146.9 & $138.4 \mathrm{a}$ & 2.9 & 3.1 & $3.0 \mathrm{c}$ \\
\hline Average & $18.8 \mathrm{~A}$ & $19.4 \mathrm{~A}$ & & $134.2 \mathrm{~A}$ & $132.3 \mathrm{~A}$ & & $3.8 \mathrm{~A}$ & $3.9 \mathrm{~A}$ & \\
\hline \multirow[t]{2}{*}{ CV $(\%)$} & & 8.9 & & & 19.6 & & & 10.2 & \\
\hline & \multicolumn{9}{|c|}{42 days } \\
\hline Redenção & $17.2^{\mathrm{ns}}$ & 15.1 & $16.1 \mathrm{~b}$ & $69.8^{\text {ns }}$ & 59.6 & $64.7 \mathrm{a}$ & $2.8^{\text {ns }}$ & 1.7 & $2.2 \mathrm{c}$ \\
\hline AF 26970 & 16.5 & 16.5 & $16.5 b$ & 63.4 & 66.5 & $64.9 \mathrm{a}$ & 3.2 & 3.3 & $3.3 b$ \\
\hline LA-1401 & 20.7 & 19.9 & $20.3 \mathrm{a}$ & 71.6 & 70.0 & $70.8 \mathrm{a}$ & 2.5 & 2.2 & $2.4 \mathrm{c}$ \\
\hline AF 19684 & 15.5 & 14.8 & $15.1 \mathrm{~b}$ & 70.3 & 69.4 & $69.9 \mathrm{a}$ & 2.4 & 2.2 & $2.3 \mathrm{c}$ \\
\hline PI-127826 & 21.1 & 20.2 & $20.6 \mathrm{a}$ & 49.7 & 55.8 & $52.7 \mathrm{a}$ & 3.8 & 4.3 & $4.1 \mathrm{a}$ \\
\hline PI-134417 & 21.4 & 21.7 & $21.5 \mathrm{a}$ & 56.7 & 55.5 & $56.1 \mathrm{a}$ & 4.0 & 3.8 & $3.9 \mathrm{a}$ \\
\hline LA-716 & 13.6 & 17.2 & $15.4 \mathrm{a}$ & 63.4 & 62.1 & $62.8 \mathrm{a}$ & 1.2 & 1.6 & $1.4 \mathrm{c}$ \\
\hline Redenção x AF 26970 & 18.1 & 18.1 & $18.1 \mathrm{~b}$ & 62.5 & 68.8 & $65.7 \mathrm{a}$ & 2.7 & 2.9 & $2.8 \mathrm{c}$ \\
\hline Redenção x LA-1401 & 18.2 & 17.0 & $17.6 \mathrm{~b}$ & 64.3 & 63.4 & $63.9 \mathrm{a}$ & 2.7 & 2.4 & $2.5 \mathrm{c}$ \\
\hline Redenção x AF 19684 & 16.6 & 16.7 & $16.6 \mathrm{~b}$ & 69.7 & 65.8 & $67.8 \mathrm{a}$ & 2.9 & 2.1 & $2.5 \mathrm{c}$ \\
\hline Redenção x PI-127826 & 21.3 & 21.3 & $21.3 \mathrm{a}$ & 66.2 & 66.2 & $66.2 \mathrm{a}$ & 4.4 & 4.4 & $4.4 \mathrm{a}$ \\
\hline Redenção x PI-134417 & 21.8 & 21.1 & $21.4 \mathrm{a}$ & 61.8 & 67.8 & $64.8 \mathrm{a}$ & 4.7 & 4.5 & $4.6 \mathrm{a}$ \\
\hline Redenção x LA-716 & 15.2 & 14.3 & $14.7 \mathrm{~b}$ & 64.0 & 60.0 & $62.0 \mathrm{a}$ & 1.1 & 1.1 & $1.1 \mathrm{~d}$ \\
\hline Average & $18.2 \mathrm{~A}$ & $18.0 \mathrm{~A}$ & & $64.1 \mathrm{~A}$ & $63.9 \mathrm{~A}$ & & $2.9 \mathrm{~A}$ & $2.8 \mathrm{~A}$ & \\
\hline $\mathrm{CV}(\%)$ & & 13.1 & & & 17.2 & & & 16.5 & \\
\hline
\end{tabular}

*Means followed by same uppercase letters in the rows and lowercase letters in the columns belong to the same group by Scott-Knott test

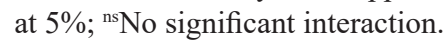


environment when compared to open field areas.

The wild species $S$. pennellii 'LA716' and hybrid 'Redenção' × 'LA-716' were more efficient regarding water use in all assessment dates (Tables 3 and 4). The highest $W U E$ for these genotypes is possibly due to their lowest transpiration rates (Tables 1 and 2). In fact, the species $S$. pennellii has as natural habitat the region belonging to the eastern
Peruvian Andes to the western Pacific Coast (Peralta et al., 2008), which is warm and dry, providing a superior performance in relation to the water efficiency use when compared to the cultivated tomato (Ealson \& Richards, 2009). Thus, the accession 'LA-716' proves to be an interesting alternative for the introgression of resistance genes to water deficit in S. lycopersicum.

The accessions 'PI-127826' and
'PI-134417' and the hybrids 'Redenção' × 'PI-127826' and 'Redenção' × 'PI134417 ' showed a higher $E i C$ in all assessment dates (Tables 4 and 5). These results are probably due to the close relation of the instantaneous carboxylation efficiency with the increments in net $\mathrm{CO}_{2}$ assimilation, as also observed by Machado et al. (2005) in citrus and Ferraz et al. (2012) in common beans ecotypes.

Table 2. Net $\mathrm{CO}_{2}$ assimilation $(A)$, internal $\mathrm{CO}_{2}$ concentration $(C i)$, and transpiration rate $(E)$ for species and interspecific hybrids of tomato cultivated under protected (P) and external (E) environments at 56, and 70 days after transplanting. Guarapuava, UNICENTRO, $2015 / 2016$.

\begin{tabular}{|c|c|c|c|c|c|c|c|c|c|}
\hline \multirow{2}{*}{ Genotype } & \multicolumn{3}{|c|}{$\boldsymbol{A}\left(\mu \mathrm{mol} \mathrm{CO} \mathrm{Cm}^{-2} \mathbf{s}^{-1}\right)$} & \multicolumn{3}{|c|}{$\boldsymbol{C i}\left(\mu \mathrm{mol} \mathrm{mol}{ }^{-1}\right)$} & \multicolumn{3}{|c|}{$\boldsymbol{E}\left(\mu \mathrm{mol} \mathrm{H} \mathrm{H}_{2} \mathbf{O} \mathbf{~ m}^{-2} \mathbf{s}^{-1}\right)$} \\
\hline & $\mathbf{P}$ & $\mathbf{E}$ & Average & $\mathbf{P}$ & $\mathbf{E}$ & Average & $\mathbf{P}$ & $\mathbf{E}$ & Average \\
\hline & \multicolumn{9}{|c|}{56 days } \\
\hline Redenção & $17.8^{\mathrm{ns}}$ & 17.8 & $17.8 \mathrm{~b}$ & $56,5 \mathrm{Bd}$ & $82.9 \mathrm{Ac}$ & $69.7 d$ & $3.8^{\mathrm{ns}}$ & 3.7 & $3.7 \mathrm{c}$ \\
\hline AF 26970 & 16.2 & 16.5 & $16.4 \mathrm{c}$ & 66.9Ac & $767.6 \mathrm{Ac}$ & $77.2 d$ & 3.7 & 3.4 & $3.6 \mathrm{c}$ \\
\hline LA-1401 & 20.7 & 17.3 & $19.0 \mathrm{a}$ & $71.6 \mathrm{Ac}$ & 64.8Ad & $68.2 \mathrm{~d}$ & 2.5 & 3.5 & $3.0 \mathrm{c}$ \\
\hline AF 19684 & 15.5 & 15.8 & $15.6 \mathrm{c}$ & $73.6 \mathrm{Bc}$ & $102.8 \mathrm{Aa}$ & $88.2 \mathrm{c}$ & 3.5 & 3.5 & $3.5 \mathrm{c}$ \\
\hline PI-127826 & 21.1 & 20.9 & $21.0 \mathrm{a}$ & 67.3Ac & 79.6Ac & $73.5 \mathrm{~d}$ & 4.5 & 4.3 & $4.4 \mathrm{~b}$ \\
\hline PI-134417 & 20.7 & 21.0 & $21.0 \mathrm{a}$ & $63.4 \mathrm{Bd}$ & $89.2 \mathrm{Ac}$ & $76.3 d$ & 4.0 & 4.5 & $4.3 b$ \\
\hline LA-716 & 15.0 & 15.0 & $15.0 \mathrm{c}$ & $72.5 \mathrm{Bc}$ & $94.3 \mathrm{Ab}$ & $83.4 \mathrm{c}$ & 2.2 & 2.5 & $2.3 \mathrm{~d}$ \\
\hline Redenção x AF 26970 & 17.8 & 18.5 & $18.2 \mathrm{~b}$ & 71.9Ac & $79.6 \mathrm{Ac}$ & $75.7 \mathrm{~d}$ & 3.4 & 3.2 & $3.3 \mathrm{c}$ \\
\hline Redenção x LA-1401 & 18.2 & 17.0 & $17.6 \mathrm{~b}$ & $83.3 \mathrm{Bb}$ & $107.2 \mathrm{Aa}$ & $95.3 b$ & 3.4 & 3.4 & $3.4 \mathrm{c}$ \\
\hline Redenção x AF 19684 & 17.4 & 17.4 & $17.4 \mathrm{~b}$ & $66.4 \mathrm{Bc}$ & $105.3 \mathrm{Aa}$ & $86.1 \mathrm{c}$ & 3.7 & 3.4 & $3.5 \mathrm{c}$ \\
\hline Redenção x PI-127826 & 21.4 & 21.6 & $21.5 \mathrm{a}$ & $59.3 \mathrm{Bd}$ & $78.6 \mathrm{Ac}$ & $69.0 \mathrm{~d}$ & 4.3 & 4.7 & $4.5 b$ \\
\hline Redenção x PI-134417 & 20.7 & 21.0 & $20.8 \mathrm{a}$ & $58.7 \mathrm{Bd}$ & $92.6 \mathrm{Ab}$ & $75.6 \mathrm{~d}$ & 5.5 & 4.6 & $5.0 \mathrm{a}$ \\
\hline Redenção x LA-716 & 15.0 & 15.2 & $15.1 \mathrm{c}$ & $104.2 \mathrm{Aa}$ & $105.7 \mathrm{Aa}$ & $104.9 \mathrm{a}$ & 2.3 & 2.3 & $2.3 \mathrm{~d}$ \\
\hline Average & $18.0 \mathrm{~A}$ & $18.1 \mathrm{~A}$ & & $70.4 \mathrm{~B}$ & $89.3 \mathrm{~A}$ & & $3.6 \mathrm{~A}$ & $3.6 \mathrm{~A}$ & \\
\hline \multirow[t]{2}{*}{ CV (\%) } & & 11.1 & & & 9.4 & & & 11.8 & \\
\hline & \multicolumn{9}{|c|}{70 days } \\
\hline Redenção & $15.0^{\mathrm{ns}}$ & 16.3 & $15.7 b$ & $99.8^{\mathrm{ns}}$ & 82.9 & $91.4 \mathrm{a}$ & $3.7^{\mathrm{ns}}$ & 3.9 & $3.8 \mathrm{c}$ \\
\hline AF 26970 & 13.3 & 13.1 & $13.2 \mathrm{c}$ & 103.5 & 101.7 & $102.6 \mathrm{a}$ & 3.9 & 3.8 & $3.8 \mathrm{c}$ \\
\hline LA-1401 & 13.4 & 14.0 & $13.7 \mathrm{c}$ & 104.1 & 105.1 & $104.6 \mathrm{a}$ & 3.6 & 3.7 & $3.7 \mathrm{c}$ \\
\hline AF 19684 & 12.9 & 12.0 & $12.5 \mathrm{~d}$ & 117.9 & 109.2 & $113.6 \mathrm{a}$ & 4.1 & 4.0 & $4.0 \mathrm{c}$ \\
\hline PI-127826 & 20.0 & 19.3 & $19.7 \mathrm{a}$ & 90.3 & 102.9 & $96.6 \mathrm{a}$ & 5.1 & 4.7 & $4.9 b$ \\
\hline PI-134417 & 19.3 & 19.3 & $19.3 \mathrm{a}$ & 98.9 & 110.7 & $104.8 \mathrm{a}$ & 5.4 & 5.6 & $5.5 \mathrm{a}$ \\
\hline LA-716 & 10.0 & 10.8 & $10.4 \mathrm{~d}$ & 104.2 & 107.6 & $105.9 \mathrm{a}$ & 3.0 & 2.9 & $3.0 \mathrm{~d}$ \\
\hline Redenção x AF 26970 & 13.6 & 13.4 & $13.5 \mathrm{c}$ & 104.5 & 109.7 & $107.1 \mathrm{a}$ & 3.7 & 3.8 & $2.6 \mathrm{c}$ \\
\hline Redenção x LA-1401 & 12.9 & 12.7 & $12.8 \mathrm{~d}$ & 96.7 & 107.2 & $101.9 \mathrm{a}$ & 3.4 & 3.5 & $3.5 \mathrm{c}$ \\
\hline Redenção x AF 19684 & 12.3 & 12.1 & $12.2 \mathrm{~d}$ & 112.3 & 109.2 & $110.7 \mathrm{a}$ & 3.6 & 3.7 & $3.7 \mathrm{c}$ \\
\hline Redenção x PI-127826 & 19.5 & 19.5 & $19.5 \mathrm{a}$ & 105.2 & 95.3 & $100.3 \mathrm{a}$ & 4.3 & 4.7 & $4.5 b$ \\
\hline Redenção x PI-134417 & 20.3 & 18.7 & $19.5 \mathrm{a}$ & 106.7 & 106.1 & $106.4 \mathrm{a}$ & 5.5 & 5.3 & $5.4 \mathrm{a}$ \\
\hline Redenção x LA-716 & 11.2 & 12.0 & $11.5 \mathrm{~d}$ & 104.2 & 106.4 & $105.3 \mathrm{a}$ & 2.5 & 2.3 & $2.4 \mathrm{~d}$ \\
\hline Average & $14.9 \mathrm{~A}$ & $14.9 \mathrm{~A}$ & & $103.7 \mathrm{~A}$ & $104.2 \mathrm{~A}$ & & $4.0 \mathrm{~A}$ & $4.0 \mathrm{~A}$ & \\
\hline CV (\%) & & 10.6 & & & 10.3 & & & 13.0 & \\
\hline
\end{tabular}

*Means followed by same uppercase letters in the rows and lowercase letters in the columns belong to the same group by Scott-Knott test

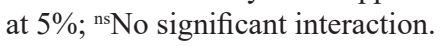


Table 3. Water use efficiency $(W U E)$ and in vivo carboxylation efficiency of Rubisco $(E i C)$ for species and interspecific hybrids of tomato cultivated under protected (P) and external (E) environments at 14, 28, and 42 days after transplanting. Guarapuava, UNICENTRO, $2015 / 2016$.

\begin{tabular}{|c|c|c|c|c|c|c|}
\hline \multirow{2}{*}{ Genotype } & \multicolumn{3}{|c|}{ WUE $\left(\mathrm{mmol} \mathrm{H}_{2} \mathrm{O} \mathrm{m}^{-2} \mathrm{~s}^{-1}\right)$} & \multicolumn{3}{|c|}{$E i C$} \\
\hline & $\mathbf{P}$ & $\mathbf{E}$ & Average & $\mathbf{P}$ & $\mathbf{E}$ & Average \\
\hline & \multicolumn{6}{|c|}{14 days } \\
\hline Redenção & $7.9^{\text {ns }}$ & 8.7 & $8.3 \mathrm{c}$ & $0.11^{\mathrm{ns}}$ & 0.09 & $0.10 \mathrm{~b}$ \\
\hline AF 26970 & 13.8 & 13.4 & $13.6 \mathrm{~b}$ & 0.12 & 0.11 & $0.11 \mathrm{~b}$ \\
\hline LA-1401 & 6.5 & 10.5 & $8.5 \mathrm{c}$ & 0.10 & 0.10 & $0.10 \mathrm{~b}$ \\
\hline AF 19684 & 6.6 & 7.6 & $7.1 \mathrm{c}$ & 0.10 & 0.08 & $0.09 b$ \\
\hline PI-127826 & 5.9 & 7.8 & $6.8 \mathrm{c}$ & 0.19 & 0.17 & $0.18 \mathrm{a}$ \\
\hline PI-134417 & 5.8 & 8.4 & $7.1 \mathrm{c}$ & 0.19 & 0.20 & $0.19 \mathrm{a}$ \\
\hline LA-716 & 19.7 & 19.5 & $19.6 \mathrm{a}$ & 0.11 & 0.10 & $0.11 \mathrm{~b}$ \\
\hline Redenção x AF 26970 & 7.1 & 7.5 & $7.3 \mathrm{c}$ & 0.11 & 0.11 & $0.11 \mathrm{~b}$ \\
\hline Redenção x LA-1401 & 6.5 & 9.2 & $7.8 \mathrm{c}$ & 0.11 & 0.10 & $0.11 b$ \\
\hline Redenção x AF 19684 & 6.6 & 8.3 & $7.4 \mathrm{c}$ & 0.11 & 0.09 & $0.10 \mathrm{~b}$ \\
\hline Redenção x PI-127826 & 5.0 & 5.9 & $5.5 \mathrm{c}$ & 0.16 & 0.17 & $0.17 \mathrm{a}$ \\
\hline Redenção x PI-134417 & 6.5 & 6.0 & $6.3 c$ & 0.18 & 0.17 & $0.17 \mathrm{a}$ \\
\hline Redenção x LA-716 & 12.4 & 13.9 & $13.1 \mathrm{~b}$ & 0.09 & 0.09 & $0.09 \mathrm{~b}$ \\
\hline Average & $8.5 \mathrm{~A}$ & $9.7 \mathrm{~A}$ & & $0.13 \mathrm{~A}$ & $0.12 \mathrm{~A}$ & \\
\hline \multirow[t]{2}{*}{ CV $(\%)$} & & 25.8 & & & 17.4 & \\
\hline & \multicolumn{6}{|c|}{28 days } \\
\hline Redenção & $3.9^{\text {ns }}$ & 4.6 & $4.3 \mathrm{c}$ & $0.09^{\text {ns }}$ & 0.12 & $0.10 \mathrm{c}$ \\
\hline AF 26970 & 4,5 & 4.2 & $4.3 \mathrm{c}$ & 0.10 & 0.12 & $0.11 \mathrm{c}$ \\
\hline LA-1401 & 5.1 & 5.5 & $5.3 \mathrm{~b}$ & 0.13 & 0.14 & $0.13 \mathrm{c}$ \\
\hline AF 19684 & 4.8 & 4.4 & $4.6 \mathrm{c}$ & 0.10 & 0.12 & $0.11 \mathrm{c}$ \\
\hline PI-127826 & 5.8 & 5.1 & $5.4 \mathrm{~b}$ & 0.31 & 0.36 & $0.31 \mathrm{a}$ \\
\hline PI-134417 & 5.3 & 5.8 & $5.5 \mathrm{~b}$ & 0.35 & 0.21 & $0.28 \mathrm{a}$ \\
\hline LA-716 & 6.0 & 6.2 & $6.1 \mathrm{a}$ & 0.11 & 0.12 & $0.12 \mathrm{c}$ \\
\hline Redenção x AF 26970 & 5.7 & 3.7 & $4.2 \mathrm{c}$ & 0.12 & 0.14 & $0.13 \mathrm{c}$ \\
\hline Redenção x LA-1401 & 4.3 & 4.4 & $4.3 \mathrm{c}$ & 0.10 & 0.16 & $0.10 \mathrm{c}$ \\
\hline Redenção x AF 19684 & 4.1 & 4.7 & $4.4 \mathrm{c}$ & 0.12 & 0.12 & $0.12 \mathrm{c}$ \\
\hline Redenção x PI-127826 & 5.3 & 4.8 & $5.0 \mathrm{~b}$ & 0.23 & 0.19 & $0.21 \mathrm{~b}$ \\
\hline Redenção x PI-134417 & 5.1 & 5.2 & $5.1 \mathrm{~b}$ & 0.30 & 0.35 & $0.33 \mathrm{a}$ \\
\hline Redenção x LA-716 & 6.0 & 6.4 & $6.2 \mathrm{a}$ & 0.14 & 0.14 & $0.14 \mathrm{c}$ \\
\hline Average & $5.0 \mathrm{~A}$ & $5.0 \mathrm{~A}$ & & $0.17 \mathrm{~A}$ & $0.17 \mathrm{~A}$ & \\
\hline \multirow[t]{2}{*}{$\mathrm{CV}(\%)$} & & 15.1 & & & 30.1 & \\
\hline & \multicolumn{6}{|c|}{42 days } \\
\hline Redenção & $6.1^{\text {ns }}$ & 9.0 & $7.5 \mathrm{c}$ & $0.27^{\mathrm{ns}}$ & 0.27 & $0.27 \mathrm{c}$ \\
\hline AF 26970 & 5.2 & 4.9 & $5.1 \mathrm{~d}$ & 0.26 & 0.25 & $0.26 \mathrm{c}$ \\
\hline LA-1401 & 8.2 & 10.8 & $9.5 \mathrm{~b}$ & 0.29 & 0.31 & $0.30 \mathrm{c}$ \\
\hline AF 19684 & 6.7 & 6.7 & $6.7 \mathrm{c}$ & 0.23 & 0.21 & $0.22 \mathrm{c}$ \\
\hline PI-127826 & 5.7 & 4.7 & $5.2 \mathrm{~d}$ & 0.43 & 0.37 & $0.40 \mathrm{a}$ \\
\hline PI-134417 & 5.3 & 5.7 & $5.5 \mathrm{~d}$ & 0.39 & 0.40 & $0.40 \mathrm{a}$ \\
\hline LA-716 & 11.8 & 11.9 & $11.9 \mathrm{a}$ & 0.22 & 0.28 & $0.25 \mathrm{c}$ \\
\hline Redenção x AF 26970 & 7.0 & 6.3 & $6.6 \mathrm{c}$ & 0.29 & 0.27 & $0.28 \mathrm{c}$ \\
\hline Redenção x LA-1401 & 6.7 & 7.3 & $7.0 \mathrm{c}$ & 0.29 & 0.27 & $0.28 \mathrm{c}$ \\
\hline Redenção x AF 19684 & 5.8 & 8.4 & $7.1 \mathrm{c}$ & 0.24 & 0.26 & $0.25 \mathrm{c}$ \\
\hline Redenção x PI-127826 & 4.8 & 4.8 & $4.8 \mathrm{~d}$ & 0.32 & 0.32 & $0.32 \mathrm{~b}$ \\
\hline Redenção x PI-134417 & 4.7 & 4.7 & $4.7 \mathrm{~d}$ & 0.35 & 0.31 & $0.33 b$ \\
\hline Redenção x LA-716 & 14.4 & 12.6 & $13.5 \mathrm{a}$ & 0.24 & 0.24 & $0.24 \mathrm{c}$ \\
\hline Average & $7.1 \mathrm{~A}$ & $7.5 \mathrm{~A}$ & & $0.29 \mathrm{~A}$ & $0.29 \mathrm{~A}$ & \\
\hline CV $(\%)$ & & 23.0 & & & 20.2 & \\
\hline
\end{tabular}

*Means followed by same uppercase letters in the rows and lowercase letters in the columns belong to the same group by Scott-Knott test

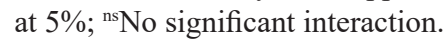


Regarding stomatal density (SD), measured only in the protected environment, the highest number of stomata on the abaxial surface of leaflets was observed in the accession 'PI-127826', followed by the accession 'PI-134417' and the hybrids 'Redenção' × 'PI- 127826' and 'Redenção' × 'PI134417 ', with values of $67.00,49.00$,
45.66, and 47.00 stomata per $300 \mu \mathrm{m}^{2}$, respectively (Table 5). On the contrary, the highest number of stomata on the adaxial surface of leaflets was observed in the hybrid 'Redenção' × 'AF 19684', with a value of 30.00 stomata per 300 $\mu \mathrm{m}^{2}$. Similarly, other studies have reported higher number of stomata in the epidermis of the abaxial surface of leaflets when compared to the adaxial surface (Tari, 2003; Cunha et al., 2013).

The basic function of a stomata is to control the entry and exit of gases and those of the abaxial surface is the main responsible for controlling transpiration, photosynthesis, and respiration in plants (Lucas \& Renzaglia, 2002). The increased number of stomata on

Table 4. Water use efficiency (WUE) and in vivo carboxylation efficiency of Rubisco $(E i C)$ for species and interspecific hybrids of tomato cultivated under protected (P) and external (E) environments at 56, and 70 days after transplanting. Guarapuava, UNICENTRO, $2015 / 2016$.

\begin{tabular}{|c|c|c|c|c|c|c|}
\hline \multirow{2}{*}{ Genotype } & \multicolumn{3}{|c|}{$W U E\left(\mathrm{mmol} \mathrm{H}_{2} \mathrm{O} \mathrm{m}^{-2} \mathrm{~s}^{-1}\right)$} & \multicolumn{3}{|c|}{ EiC } \\
\hline & $\mathbf{P}$ & $\mathbf{E}$ & Average & $\mathbf{P}$ & $\mathbf{E}$ & Average \\
\hline & \multicolumn{6}{|c|}{56 days } \\
\hline Redenção & $4.7 \mathrm{Ab}$ & $4.8 \mathrm{Ab} 4.8 \mathrm{~b}$ & $4.8 \mathrm{~b}$ & $0.32 \mathrm{Ab}$ & $0.22 \mathrm{Ba}$ & $0.27 b$ \\
\hline AF 26970 & $4.4 \mathrm{Ab}$ & $4.9 \mathrm{Ab}$ & $4.6 \mathrm{~b}$ & $0.24 \mathrm{Ac}$ & $0.21 \mathrm{Aa}$ & $0.23 \mathrm{c}$ \\
\hline LA-1401 & $8.2 \mathrm{Aa}$ & $4.9 \mathrm{Bb}$ & $6.6 \mathrm{a}$ & $0.29 \mathrm{Ab}$ & $0.27 \mathrm{Aa}$ & $0.28 b$ \\
\hline AF 19684 & $4.5 \mathrm{Ab}$ & $4.5 \mathrm{Ab}$ & $4.5 b$ & $0.21 \mathrm{Ac}$ & $0.15 \mathrm{Bb}$ & $0.18 \mathrm{~d}$ \\
\hline PI-127826 & $4.7 \mathrm{Ab}$ & $4.9 \mathrm{Ab}$ & $4.8 b$ & $0.31 \mathrm{Ab}$ & $0.26 \mathrm{Aa}$ & $0.23 \mathrm{a}$ \\
\hline PI-134417 & $5.2 \mathrm{Ab}$ & $4.7 \mathrm{Ab}$ & $4.9 \mathrm{~b}$ & $0.33 \mathrm{Ab}$ & $0.24 \mathrm{Ba}$ & $0.28 \mathrm{a}$ \\
\hline LA-716 & 7.0Aa & $6.0 \mathrm{Aa}$ & $6.5 \mathrm{a}$ & $0.21 \mathrm{Ac}$ & $0.16 \mathrm{Ab}$ & $0.18 \mathrm{~d}$ \\
\hline Redenção x AF 26970 & $5.3 \mathrm{Ab}$ & $5.8 \mathrm{Aa}$ & $5.5 b$ & $0.25 \mathrm{Ac}$ & $0.24 \mathrm{Aa}$ & $0.24 b$ \\
\hline Redenção x LA-1401 & $5.4 \mathrm{Ab}$ & $5.1 \mathrm{Ab}$ & $5.3 b$ & $0.22 \mathrm{Ac}$ & $0.16 \mathrm{Bb}$ & $0.19 \mathrm{~d}$ \\
\hline Redenção x AF 19684 & $5.8 \mathrm{Ab}$ & $5.3 \mathrm{Ab}$ & $5.0 \mathrm{~b}$ & $0.26 \mathrm{Ac}$ & $0.16 \mathrm{Bb}$ & $0.21 \mathrm{c}$ \\
\hline Redenção x PI-127826 & $5.0 \mathrm{Ab}$ & $5,7 \mathrm{Ab}$ & $4.8 \mathrm{~b}$ & $0.37 \mathrm{Aa}$ & $0.28 \mathrm{Ba}$ & $0.32 \mathrm{a}$ \\
\hline Redenção x PI-134417 & $3.9 \mathrm{Ab}$ & $4.6 \mathrm{Ab}$ & $4.3 b$ & $0.36 \mathrm{Aa}$ & $0.23 \mathrm{Ba}$ & $0.29 \mathrm{a}$ \\
\hline Redenção x LA-716 & $6.8 \mathrm{Aa}$ & $6.6 \mathrm{Aa}$ & $6.7 \mathrm{a}$ & $0.14 \mathrm{Ad}$ & $0.14 \mathrm{Ab}$ & $0.14 \mathrm{c}$ \\
\hline Average & $5.4 \mathrm{~A}$ & $5.1 \mathrm{~A}$ & & $0.27 \mathrm{~A}$ & $0.21 \mathrm{~B}$ & \\
\hline \multirow[t]{2}{*}{ CV (\%) } & & 16.0 & & & 12.6 & \\
\hline & \multicolumn{6}{|c|}{70 days } \\
\hline Redenção & $4.0^{\text {ns }}$ & 4.1 & $4.1 \mathrm{a}$ & $0.15^{\mathrm{ns}}$ & 0.20 & $0.18 \mathrm{a}$ \\
\hline AF 26970 & 3.4 & 3.5 & $3.4 \mathrm{~b}$ & 0.13 & 0.13 & $0.13 b$ \\
\hline LA-1401 & 3.7 & 3.8 & $3.8 \mathrm{~b}$ & 0.13 & 0.13 & $0.13 b$ \\
\hline AF 19684 & 3.2 & 3.1 & $3.1 b$ & 0.11 & 0.11 & $0.11 \mathrm{c}$ \\
\hline PI-127826 & 4.1 & 4.2 & $4.1 \mathrm{a}$ & 0.22 & 0.19 & $0.21 \mathrm{a}$ \\
\hline PI-134417 & 3.6 & 3.5 & $3.5 b$ & 0.20 & 0.18 & $0.19 \mathrm{a}$ \\
\hline LA-716 & 3.5 & 4.0 & $3.7 b$ & 0.10 & 0.10 & $0.10 \mathrm{c}$ \\
\hline Redenção x AF 26970 & 3.7 & 3.8 & $3.8 \mathrm{~b}$ & 0.13 & 0.13 & $0.13 b$ \\
\hline Redenção x LA-1401 & 3.8 & 3.6 & $3.7 b$ & 0.13 & 0.12 & $0.13 b$ \\
\hline Redenção x AF 19684 & 3.4 & 3.2 & $3.3 b$ & 0.11 & 0.11 & $0.11 \mathrm{c}$ \\
\hline Redenção x PI-127826 & 3.6 & 4.2 & $3.9 b$ & 0.19 & 0.21 & $0.20 \mathrm{a}$ \\
\hline Redenção x PI-134417 & 3.7 & 3.5 & $3.6 b$ & 0.19 & 0.18 & $0.18 \mathrm{a}$ \\
\hline Redenção x LA-716 & 4.7 & 5.3 & $5.0 \mathrm{a}$ & 0.11 & 0.11 & $0.11 \mathrm{c}$ \\
\hline Average & $3.8 \mathrm{~A}$ & $3.8 \mathrm{~A}$ & & $0.15 \mathrm{~A}$ & $0.15 \mathrm{~A}$ & \\
\hline CV (\%) & & 19.7 & & & 14.5 & \\
\hline
\end{tabular}

*Means followed by same uppercase letters in the rows and lowercase letters in the columns belong to the same group by Scott-Knott test

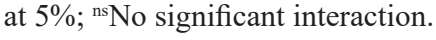


Table 5. Stomatal density (SD) on the abaxial and adaxial surfaces in first-order leaflets for species and interspecific hybrids of tomato cultivated under protected environment. Guarapuava, UNICENTRO, 2015/2016.

\begin{tabular}{lcc}
\hline \multirow{2}{*}{ Genotype } & \multicolumn{2}{c}{ SD $\left(\mathbf{3 0 0} \mu \mathbf{m}^{2}\right)$} \\
\cline { 2 - 3 } Redenção & Abaxial & Adaxial \\
AF 26970 & $33.5 \mathrm{~d}$ & $11.0 \mathrm{c}$ \\
LA-1401 & $34.7 \mathrm{~d}$ & $14.7 \mathrm{~b}$ \\
AF 19684 & $26.7 \mathrm{e}$ & $4.7 \mathrm{~d}$ \\
PI-127826 & $20.0 \mathrm{f}$ & $5.7 \mathrm{~d}$ \\
PI-134417 & $67.0 \mathrm{a}$ & $6.7 \mathrm{~d}$ \\
LA-716 & $49.0 \mathrm{~b}$ & $1.7 \mathrm{e}$ \\
Redenção x AF 26970 & $11.0 \mathrm{~g}$ & $6.7 \mathrm{~d}$ \\
Redenção x LA-1401 & $33.0 \mathrm{~d}$ & $7.7 \mathrm{~d}$ \\
Redenção x AF 19684 & $40.0 \mathrm{c}$ & $17.7 \mathrm{~b}$ \\
Redenção x PI-127826 & $42.0 \mathrm{c}$ & $30.0 \mathrm{a}$ \\
Redenção x PI-134417 & $45.7 \mathrm{~b}$ & $16.7 \mathrm{~b}$ \\
Redenção x LA-716 & $47.0 \mathrm{~b}$ & $13.0 \mathrm{c}$ \\
\hline Average & $24.7 \mathrm{e}$ & $10.3 \mathrm{c}$ \\
CV (\%) & 36.2 & 11.3 \\
\hline
\end{tabular}

*Means followed by same lowercase letters in the columns belong to the same group by Scott-Knott test at 5\%.

the abaxial surface of the genotypes 'PI-127826', 'PI-134417', 'Redenção' × 'PI-127826', and 'Redenção' × 'PI134417 ' is possibly the main factor that provided higher net $\mathrm{CO}_{2}$ assimilation, transpiration, and instantaneous in vivo carboxylation efficiency of Rubisco.

Depending on the characteristics, we can consider the existence of a diversity of physiological responses between tomato species. The results of photosynthetic behavior observed in our study may collaborate with breeding programs, providing practical information that allows developing and selecting genotypes that best adapt to certain growing conditions.

The importance of qualitative and quantitative photosynthetic behavior in the development and plant growth is commonly reported in the literature. Considering this and that the accessions 'PI-127826' and 'PI-134417' and the respective interspecific $\mathrm{F}_{1}$ hybrids 'Redenção' × 'PI-127826' and 'Redenção' x 'PI$134417^{\prime}$ presented higher net $\mathrm{CO}_{2}$ assimilation, instantaneous in vivo carboxylation efficiency of Rubisco, and stomatal density on the abaxial surface, the descendants of the varieties hirsutum and glabratum proved to be an interesting alternative for breeding programs that aim to make advances in obtaining genotypes that present improvement in their photosynthetic characteristics. Due to the higher water use efficiency, the accession 'LA-716' and the hybrid 'LA-716' × 'Redenção' proved to be an interesting genetic resource for tomato breeding programs, aiming at tolerance to water deficit.

\section{REFERENCES}

ADAMS, WW; STEWART, JJ; COHU, CM; MULLER, O; DEMMIG-ADAMS, B. 2016. Habitat temperature and precipitation of Arabidopsis thaliana ecotypes determine the response of foliar vasculature, photosynthesis, and transpiration to growth temperature. Frontiers in Plant Science 7: 1-18.

BERGOUGNOUX, V. 2014. The history of tomato: From domestication to biopharming. Biotechnology Advances 32:170-189.

BILGIN, DD; AVALA, JA; ZHU, J; CLOUGH, SJ; ORT DR; DELUCIA, EH. 2010. Biotic stress globally downregulates photosynthesis genes. Plant, Cell \& Environment 33: 1597613.
CUNHA, VC; SANTOS, JB; FERREIRA, EA; CABRAL, CM; SILVA, DV; GANDINI, EM. 2013. Anatomia foliar comparativa em espécies de guanxuma. Planta Daninha 31: 341-349.

DRIEVER, SM; LAWSON, T; ANDRALOJC, PJ; RAINES, CA; PARRY, MAJ. 2014. Natural variation in photosynthetic capacity, growth, and yield in 64 field-grown wheat genotypes. Journal of Experimental Botany 65: 4959-4973.

EALSON, HM; RICHARDS, JH. 2009. Drought response in self-compatible species of tomato (Solanaceae). American Journal of Botany 96: 605-611.

EASLON, HM; ST.CLAIR, DA; BLOOM, AJ. 2014. An introgression from wild tomato (Solanum habrochaites) affects tomato photosynthesis and water relations. Crop Science 54: 779-784.

FERRAZ, RLS; MELO, AS; SUASSUNA, JF; BRITO, MEB; FERNANDES, PD; NUNES JUNIOR, ES. 2012. Trocas gasosas e eficiência fotossintética em ecotipos de feijoeiro cultivados no semiárido. Pesquisa Agropecuária Tropical 42: 181-188.

GURURANI, M; MOHANTA, T; BAE, H. 2015. Current understanding of the interplay between phytohormones and photosynthesis under environmental stress. International Journal of Molecular Sciences 16: 19055-19085.

HILSDORF, AWS; HALLERMAN, EM. 2017. Genetic resources of neotropical fishes. Berlim: Springer. 258p.

HURTADO, FD; GIL, MA; ZUBIAUR, YM; AGUILERA, JG; XAVIER, CAD; ZERBINI JUNIOR, FM; SILVA, DJH. 2012. Fontes de resistência em tomateiro aos begomovírus bissegmentados tomato yellow spot virus e tomato severe rugose virus. Horticultura Brasileira 30: 639-644.

LIU, H; OUYANG, B; ZHANG, J; WANG, T; LI, H; ZHANG, Y; YU, C; YE, Z. 2012. Differential modulation of photosynthesis, signaling, and transcriptional regulation between tolerant and sensitive tomato genotypes under cold stress. PLoS One 7: 1-16.

LUCAS, JR; RENZAGLIA, KS. 2002. Structure and function of hornwort stomata. Microscopy and Microanalysis 8: 1090-1092.

LUCINI, T; FARIA, MV; ROHDE, C; RESENDE, JTV; OLIVEIRA, JRF. 2015. Acylsugar and the role of tricomes in tomato genotypes resistance to Tetranychus urticae. ArthropodPlant Interactions 9: 45-53.

MACHADO, EC; SCHMIDT, PT; MEDINA, CL; RIBEIRO, RV.2005. Respostas da fotossíntese a fatores ambientais em três espécies de citros. Pesquisa Agropecuária Brasileira 40: 1161-1170

MORALES, RGF; RESENDE, LV; BORDINI, IC; GALVAO, AG; RESENDE, FC. 2015. Caracterização do tomateiro submetido ao déficit hídrico. Scientia Agraria 16: 9-17.

PERALTA, IE; SPOONER, DM; KNAPP, S. 2008. Taxonomy of wild tomatoes and their relatives (Solanum sect. Lycopersicoides, sect. Juglandifolia, sect. Lycopersicon; Solanaceae). Systematic Botany Monographs 8: 1-186. 
POUDYALA, D; KHATRIA, L; UPTMOORA, R. 2015. An introgression of Solanum habrochaites in the rootstock improves stomatal regulation and leaf area development of grafted tomatoes under drought and low root-zone-temperatures. Advances in Crop Science and Technology 3: 1-11.

RAMOS, ARP; AMARO, ACE; MACEDO, AC; SOUZA, ER; RODRIGUES, JD; ONO, EO. 2015. Acúmulo de carboidratos no desenvolvimento de tomateiro tratado com produtos químicos. Semina. Ciências Agrárias 36: 705-718.

SAIBO, NJM; LOURENCO, T; OLIVEIRA, MM. 2009. Transcription factors and regulation of photosynthetic and related metabolism under environmental stresses. Annals of Botany
103: 609-623.

SILVA, FAS; AZEVEDO, CAV. 2016. The assistat software version 7.7 and its use in the analysis of experimental data. African Journal of Agricultural Research 11: 3733-3740.

SOARES, LAA; SOUSA, JRM; BRITO, MEB; ANDRADE, EMG; SÁ, FVS; SILVA, ECB. 2012. Influência de diferentes lâminas de irrigação nas trocas gasosas do tomateiro na fase vegetativa. Agropecuária Científica no Semi-Árido 8: 118-122.

TARI, I. 2003. Abaxial and adaxial stomatal density, stomatal conductances and water status of bean primary leaves as affected by paclobutrazol. Biologia Plantarum 47: 215-220.

WREGE, MS; STEINMETZ, S; REISSER
JUNIOR, C; ALMEIDA, IR. 2011. Atlas climático da região sul do Brasil: Estados do Paraná, Santa Catarina e Rio Grande do Sul. Pelotas: Embrapa Clima Temperado, Colombo: Embrapa Florestas. 336p.

ZEIST, AR; RESENDE, JTV; SILVA, IFL; OLIVEIRA, JRF; FARIA, CMDR; GIACOBBO, CL. 2017a. Agronomic characteristics of tomato plant cultivar Santa Cruz Kada grafted on species of the genus Solanum. HorticulturaBrasileira 35: 419-424.

ZEIST, AR; PIVA, R; RESENDE, JTV; SILVA, IFL; ATHANAZIO, JC; RODRIGUES, JD. 2017b. Physiological and agronomic traits of cabbage plants hybrid Fuyutoyo ${ }^{\circledR}$ sprayed with plant growth regulators. Horticultura Brasileira 35: 210-215. 